\title{
Histopathology and other aspects of echinostome infection in freshwater fishes of the South Western Ghats, India
}

\section{Puthiyakandy Janardhanan Jithila and Puthanpurayil Kandambeth Prasadan*}

Ecological Parasitology and Tropical Biodiversity Laboratory. Department of Zoology. Kannur University. Mananthavady Campus. Wayanad - 670645. Kerala, India. *Email: prasadanpk@kannuruniv.ac.in.

Abstract. While investigating the trematode parasite infestation in the freshwater fishes of South Western Ghats, India we came across echinostome infection in three species of fishes Pseudosphromenus cupanus, Lepidocephalichthys thermlis and Aplochelus lineatus. Detailed histopathological studies on the infected kidney of the freshwater fish $L$. thermlis revealed severe damage and degeneration of their cells. The prevalence, intensity and mean abundance of infection of Echinostoma sp. in the three fishes were also recorded. The prevalences of Echinostoma sp. infection in the freshwater fishes P. cupanus, $A$. lineatus and $L$. thermalis were $5.55 \%, 66.66 \%$ and $25 \%$, the intensities of infection were $4.5,36$ and 1 , and the mean abundances were $0.25,24$ and 0.25 , respectively.

Keywords: Echinostoma sp.; freshwater fishes; histopathology; Western Ghats.

\section{Introduction}

Fishes serve as hosts for many parasites including metacercariae and adult trematodes and that may result in various pathological effects (Seppänen et al., 2009; Jyrwa et al., 2016).
Received

May 21, 2019

Accepted

August 23, 2019

Released

August 31, 2019

Full Text Article

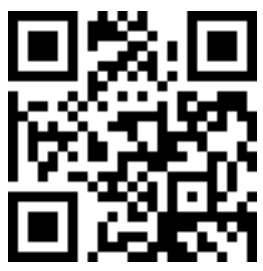

ORCiD
0000-0002-8770-7994
Puthiyakandy
Janardhanan Jithila
(1) 0000-0001-7228-8435
Puthanpurayil
Kandambeth Prasadan 
have a range of second intermediate hosts including gastropods, bivalved molluscs, fishes and amphibians. The nature and structure of the echinostome cysts, and their localization vary with hosts (Huffman and Fried, 1990; Fried, 2001).

Echinostoma spp. have been recognized as important zoonotic agents and cases of human echinostomiasis have been reported from various geographical areas (Chai et al., 1994; Haseeb and Eveland, 2002; Sripa et al., 2010; Chai et al., 2012; Sah et al., 2018). Eating raw or improperly cooked or processed fish are the main sources of infection to humans. According to Toledo and Esteban (2016) human echinostomiasis is attributed to a minimum of 24 species that are endemic to Southeast Asia and the Far East, including the mainland China, Taiwan, India, Korea, Malaysia, Philippines and Indonesia. Various studies on human echinostomiasis have been reported from India (Maji et al., 1993; Tandon et al., 2014).

The paper describes the pathological effects of Echinostoma sp. on the kidney of the freshwater fish L. thermalis. The paper also describes the prevalence, intensity and mean abundance of Echinostoma sp. infection in the freshwater fishes $P$. cupanus, A. lineatus and L. thermalis.

\section{Materials and methods}

\section{Histopathology}

Infected tissues were washed thoroughly with water and preserved in buffered formalin for about $24 \mathrm{~h}$. After thorough washing the specimens were dehydrated in alcohol series \& acetone and were cleared in methyl benzoate. Paraffin blocks were prepared with molten wax maintained at $58{ }^{\circ} \mathrm{C}$. Serial sections having $7 \mu \mathrm{m}$ thick taken using a Microtec rotatory microtome (Germany) were stained with haematoxylin and eosin to study the histopathology and cellular infiltration at the site of parasite attachment. The DPX mounted sections were observed under Nikon ECLIPSE Ni$\mathrm{U}$ phase contrast research microscope and photographed with the Nikon Y-TV55 camera attached to the microscope.

Specimen preparation and studies on prevalence, intensity and mean abundance of infection

Host specimens were collected from small rivulets in Wayanad using sweep net. The collected fishes were sacrificed by cervical rupture and all organs were examined under a Labomed (Luxeo 4Z) stereozoom microscope for larval digeneans. Metacercariae were transferred to $0.75 \%$ saline and studied under Nikon ECLIPSE Ni-U phase contrast research microscope (Nikon, Japan). Permanent slides of excysted metacercariae were prepared after fixing the flukes in $5 \%$ formalin and staining them in acetocarmine. The procedure outlined by Cantwell (1981) was followed for staining. Prevalence, intensity and mean abundance of infection were measured following Bush et al. (1997).

\section{Results}

\section{Histopathology}

The histological study of infected kidney of $L$. thermalis showed severe damage (Figure 1) on its structure. The heavy burden of encysted metacercariae in the kidney resulted in the degeneration of cells. The tissues surrounding the cyst were necrotic. Degeneration in the epithelial cells of renal tubule with hypertrophied cells and narrowing of tubular lumen was evident (Figure 2). The cells surrounding the metacercarial cyst was necrotic and the pathogenic effects included the degeneration of glomerulus and hematopoietic tissue (Figure 3). Acute granuloma was evident. The histopathology revealed severe tissue damage in the infected fish. 


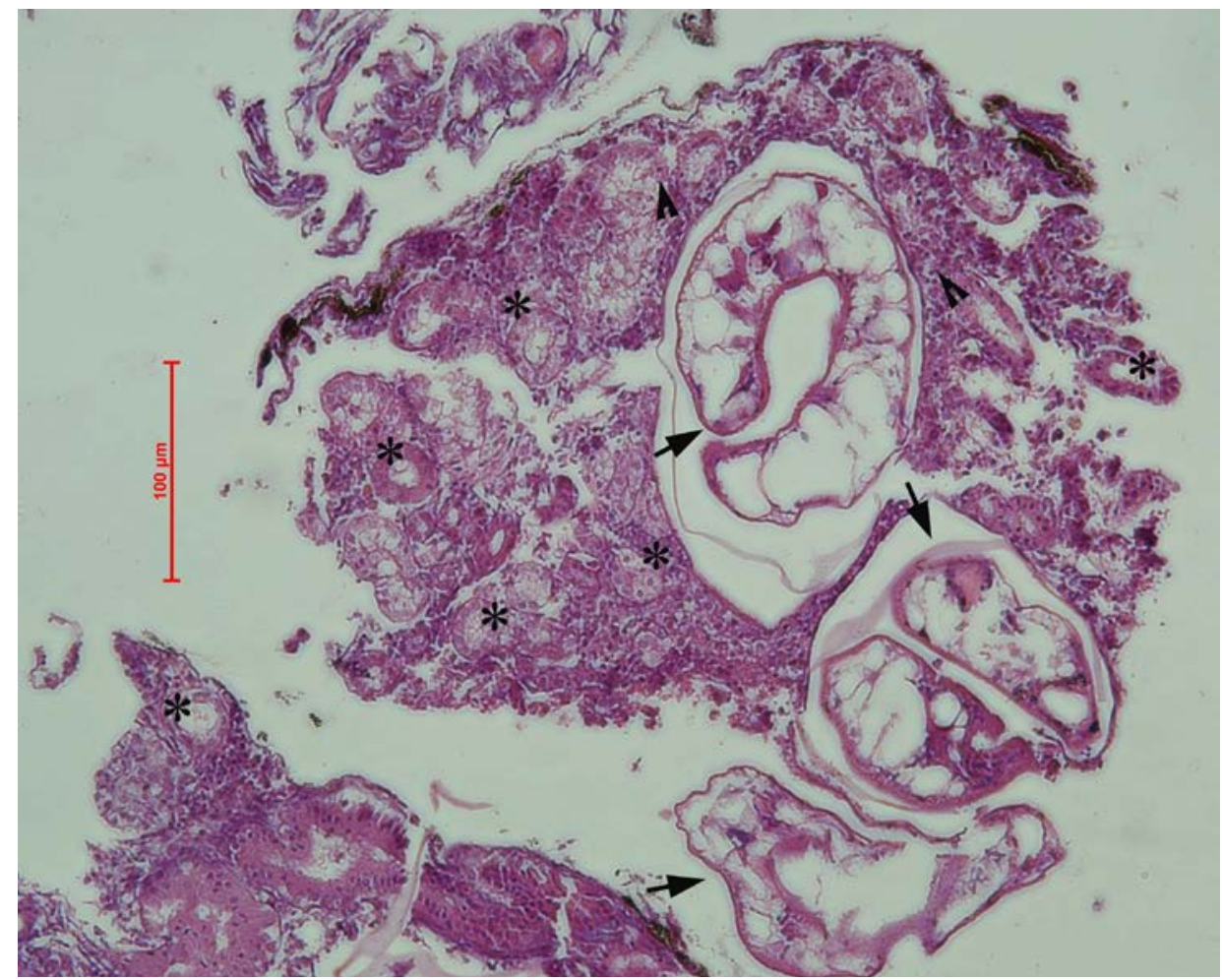

Figure 1. Photomicrograph of the transverse section of infected kidney showing severe tissue damage. Metacercaria (arrow), tissue damage (arrow head) and degeneration of cells in the renal tubule (asterisk).

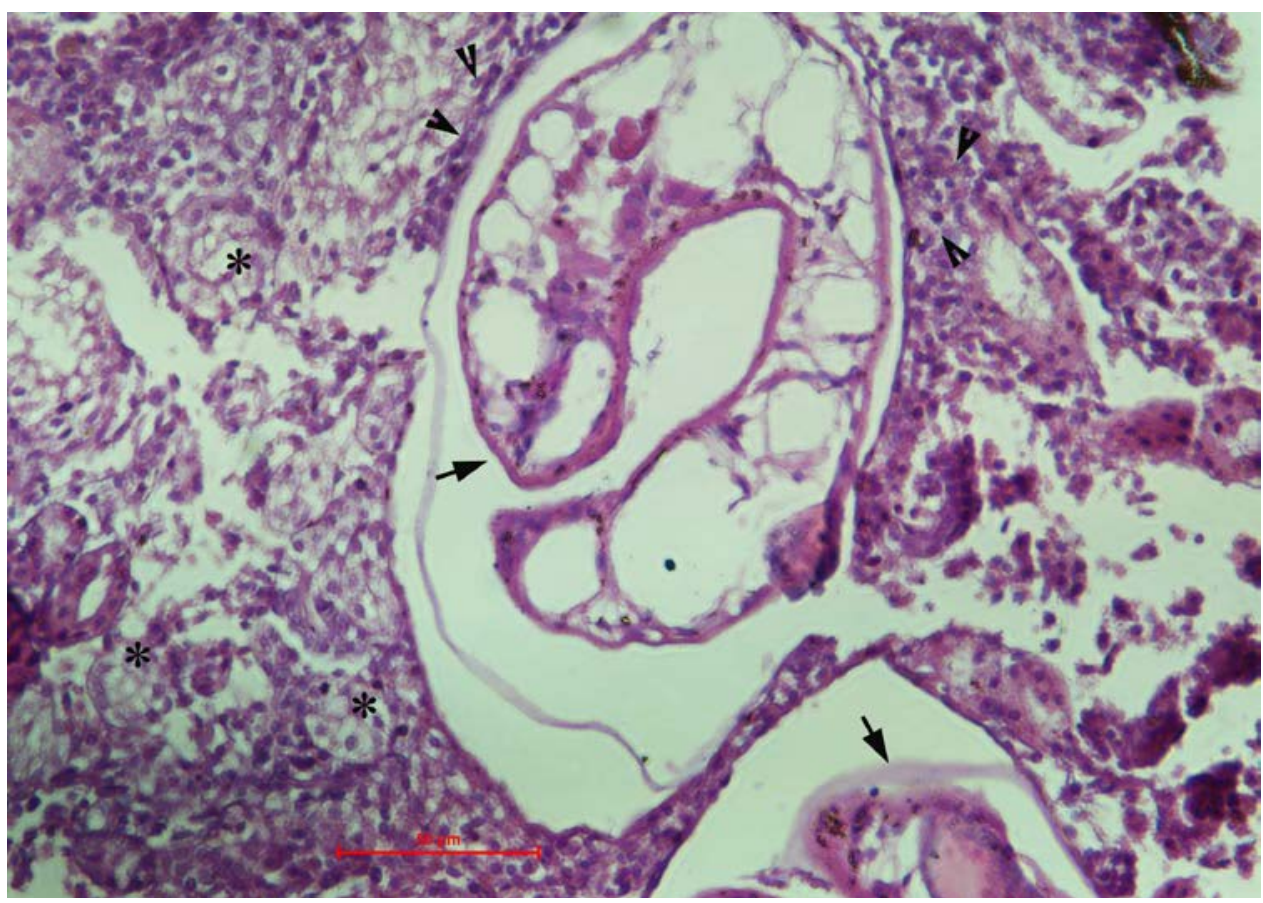

Figure 2. Photomicrograph of the transverse section of infected kidney showing degeneration of epithelial cells in the renal tubules (asterisk), necrotic cells surrounding the metacercariae (arrow head) and metacercariae (arrow). 


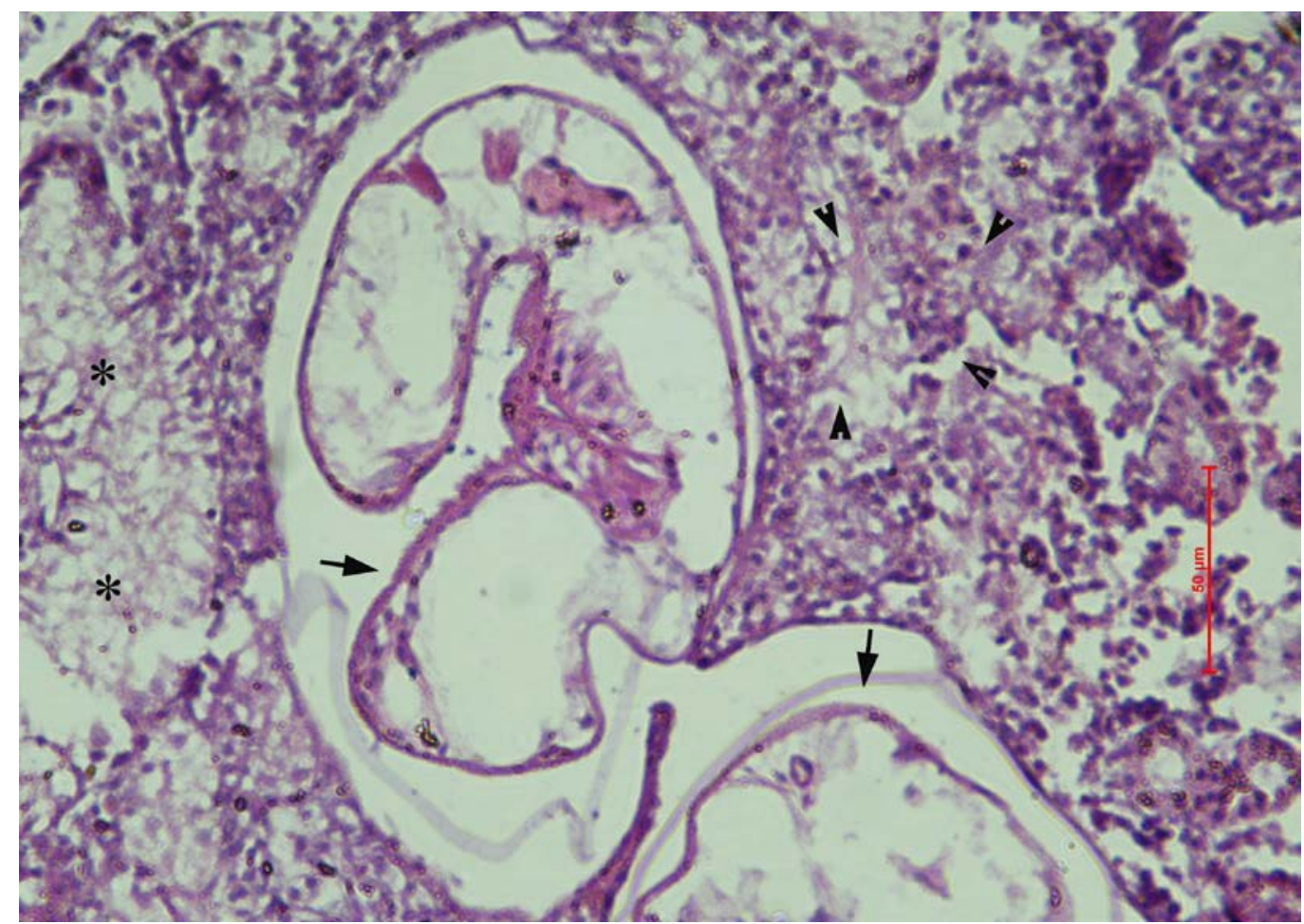

Figure 3. Photomicrograph of the transverse section of infected kidney showing degeneration of glomerulus (asterisk) and hematopoietic tissue (arrow head); metacercariae (arrow).

\section{Prevalence, intensity and mean abundance of infection \\ The freshwater fishes, $P$. cupanus,} A. lineatus and L. thermalis, collected from Moolithodu of Wayanad were infected with Echinostoma sp. The metacercariae (Figure 4) were found encysted in the kidney of $P$. cupanus \& $L$. thermalis and mesenteries of $A$. lineatus. The prevalence, intensity and mean abundance of infection varies with hosts (Table 1).

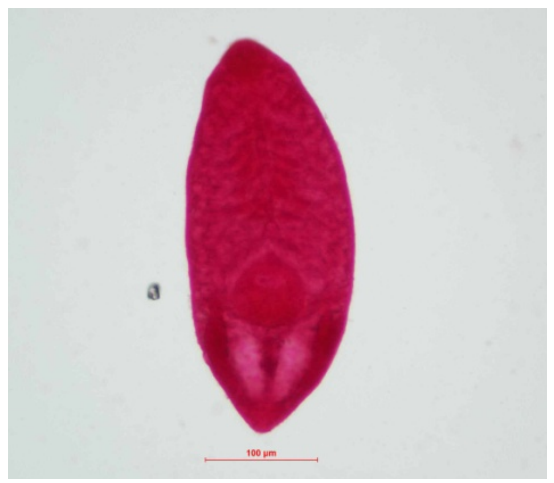

Figure 4. The excysted metacercaria of Echinostoma sp.

Table 1. Prevalence, intensity and mean abundance of infection in fish hosts

\begin{tabular}{|l|c|c|c|}
\hline Host & $\begin{array}{c}\text { Prevalence of } \\
\text { Infection (\%) }\end{array}$ & $\begin{array}{c}\text { Intensity of } \\
\text { Infection }\end{array}$ & $\begin{array}{c}\text { Mean } \\
\text { abundance }\end{array}$ \\
\hline Pseudosphromenus cupanus & $2 / 36(5.55)$ & 4.5 & 0.25 \\
\hline Lepidocephalichthys thermlis & $2 / 3(66.66)$ & 36 & 24 \\
\hline Aplochelus lineatus & $2 / 8(25)$ & 1 & 0.25 \\
\hline
\end{tabular}




\section{Discussion}

1809 The genus Echinostoma Rudolphi, Echinostomatidae Looss, 1899 with Echinostoma revolutum (Froelich, 1802) Dietz, 1909 as its type species. More than 130 species of Echinostoma have been reported from various parts of the globe (Nasir, 1960; Joet and Umathevy, 1966; Lie and Basch, 1967; Fried et al., 1990; Huffman and Fried, 1990; Toledo et al., 2009). The Echinostoma reported from India includes, Echinostoma revolutum (Froelich, 1802) Dietz, 1909; E. govindum Moghe, 1932; E. bhattacharyai Verma, 1936; E. chasma Lal, 1939; E. ivaniosi Mohandas, 1973; E. eduardoi Ghosh and Chauhan, 1977; E. minimum (Verma, 1936) Srivastava, 1982.

In the present study the histopathology revealed severe granuloma in the infected kidney. The development of granulomas of fibrotic tissue and leukocytes around Echinostome cysts in tadpole kidneys were observed by Holland et al. (2006) and similar responses were observed in adult frog's kidneys (Martin and Conn, 1990). According to Evans (1974) histopathology of kidney of cutthroat trout infected with Sanguinicola kiamathensis showed necrosis or hypertrophy of renal epithelial cells and the degeneration of epithelial cells of the renal tubule, and this may lead to the renal failure. According to Fried et al. (1997) echinostomes can induce oedema and inhibit tadpole growth. Holland et al. (2006) observed oedema and lack of visible glomeruli in the Echinostome infected tadpoles. The present study showed disruption of the glomeruli by metacercarial cysts and this may lead to the degeneration of the glomerulus. The study suggests that the disruption of the glomeruli could have a grave impact on renal function.

According to Poulin and Mouillot (2005) the prevalence, intensity, or abundance of infection by a particular parasite differs among its host species and the present study agrees with the findings of Poulin and Mouillot (2005). An earlier study of Chai et al. (1985) revealed a high infection rate $(41.6 \%)$ and density (8.1) of E. hortense in the loach, Misgurnus anguillicaudatus from Korea whereas in the present study the prevalence, intensity and mean abundance of Echinostoma sp. infection in the loach, $L$. thermalis were relatively higher: $66.66 \%, 36$ and 24 , respectively.

\section{Acknowledgements}

The authors are grateful to the Kannur University for providing necessary facilities. One of the authors (Jithila P J) is grateful to the Kerala State Council for Science, Technology and Environment (KSCSTE), Government of Kerala for the Research Fellowship.

All applicable international, national, and/or institutional guidelines for the care and use of animals were followed. All procedures performed in the study involving animals were in accordance with the ethical standards of the institution or practice at which the study was conducted.

\section{Conflict of interest}

The authors declare that there is no conflict of interest between them.

\section{References}

Bush, A. O.; Lafferty, K. D.; Lotz, J. M.; Shostak, A. W. Parasitology meets ecology on its own terms: Margolis et al. revisited. Journal of Parasitology, v. 83, p. 575-583, 1997.

Cantwell, G. E. Methods for invertebrates. In: Clark, G. (Ed.). Staining procedures. Baltimore: Williams and Wilkins, 1981. p. 255-280.

Chai, J. Y.; Hong, S. J.; Sohn, W. M.; Lee, S. H.; Seo, B. S. Studies on intestinal trematodes in Korea. XVI. Infection status of loaches with the metacercariae of Echinostoma hortense. 
Korean Journal of Parasitology, v. 23, p. 1823, 1985.

Chai, J. Y.; Hong, S. T.; Lee, S. H.; Lee, G. C.; Min, Y. I. A case of echinostomiasis with ulcerative lesions in the duodenum. Korean Journal of Parasitology, v. 32, p. 201-204, 1994.

Chai, J. Y.; Sohn, W. M.; Yong, T. S.; Eom, K. S.; Min, D. Y.; Hoang, E. H.; Phammasack, B.; Insisiengmay, B.; Rim, H. J. Echinostome flukes recovered from humans in Khammouane Province, Lao PDR. Korean Journal of Parasitology, v. 50, p. 269-272, 2012.

Esteban, J. G.; Muñoz-Antoli, C. Echinostomes: Systematics and life cycles. In: Fried, B.; Toledo, R. (Eds.). The biology of echinostomes. New York: Springer, 2009. https://doi.org/10.1007/978-0-387-095776_1

Evans, W. A. The histopathology of cutthroat trout experimentally infected with the blood fluke Sanguinicola klamathensis. Journal of Wildlife Diseases, v. 10, no. 3, p. 243-248, 1974. https://doi.org/10.7589/0090-355810.3.243

Fried, B. Biology of echinostomes except echinostoma. Advances in Parasitology, v. 49, p. 163-210, 2001.

Fried, B.; Huffman, J. E.; Weiss, P. M. Single and multiple worm infections of Echinostoma caproni (Trematoda) in the golden hamster. Journal of Helminthology, v. 64, p. 75-78, 1990.

Fried, B.; Pane, P. L.; Reddy, A. Experimental infection of Rana pipiens tadpoles with Echinostoma trivolvis cercariae. Parasitology Research, v. 83, p. 666-669, 1997.

Haseeb, M. A.; Eveland, L. K. Human echinostomasis: Mechanisms of pathogenesis and host resistance. In: Fried, B.; Graczyk, T. K. (Eds.). Echinostomes as models for biological research. Dordrecht: Kluwer, 2002. p. 83-98.

Holland, M. P.; Skelly, D. K.; Kashgarian, M.; Bolden, S. R.; Harrison, L. M.; Cappello, M. Echinostome infection in green frogs (Rana clamitans) is stage and age dependent. Journal of Zoology, v. 271, p. 455-462, 2006. https://doi.org/10.1111/j.1469-7998.2006. 00229.x
Huffman, J. E.; Fried, B. Echinostoma and echinostomiasis. Advances in Parasitology, v. 29, p. 215-269, 1990.

Joet, L. K.; Umathevy, T. Studies on Echinostomatidae (Trematoda) in Malaya. XI. The life history of Echinostoma hystricosum sp. n. Journal of Parasitology, v. 52 p. 449$453,1966$.

Jyrwa, D. B.; Thapa, S.; Tandon, V. Helminth parasite spectrum of fishes in Meghalaya, Northeast India: A checklist. Journal of Parasitogy Diseases, v. 40, p. 312-329, 2016.

Lie, K. J.; Basch, P. F. The life history of Echinostoma paraensei sp. n. (Trematoda: Echinostomatidae). Journal of Parasitology, v. 5 , p. 1192-1199, 1967.

Maji, A. K.; Bera, D. K.; Manna, B.; Nandy, A.; Addy, M.; Bandyopadhyay, A. K. First record of human infection with Echinostoma malayanum in India. Transactions of the Royal Society of Tropical Medicine \& Hygiene, v. 87, p. 673, 1993. https://doi.org/10.1016/00359203(93)90285-X

Martin, T. R.; Conn, D. B. The pathogenicity, localization, and cyst structure of echinostomatid metacercariae (trematoda) infecting the kidneys of the frogs Rana clamitans and Rana pipiens. Journal of Parasitology, v. 76, p. 414-419, 1990.

Nasir, P. Studies on the Life History of Echinostoma nudicaudatum n. sp. (Echinostomatidae: Trematoda). Journal of Parasitology, v. 46, p. 833-847, 1960.

Poulin, R.; Mouillot, D. Host specificity and the probability of discovering species of helminth parasites. Parasitology, v. 130, p. 709-715, 2005.

Sah, R.; Khadka, S.; Hamal, R.; Poudyal, S. Human echinostomiasis: A case report. BMC Research Notes, 11:17, 2018. https://doi.org/10.1186/s13104-018-3133Z

Seppänen, E.; Kuukka, H.; Voutilainen, A.; Huuskonen, H.; Peuhkuri, N. Metabolic depression and spleen and liver enlargement in juvenile Arctic charr Salvelinus alpinus exposed to chronic parasite infection. Journal of Fish Biology, v. 74, p. 553-561, $2009 . \quad$ https://doi.org/10.1111/j.10958649.2008.02144.x 
Sripa, B.; Kaewkes, S.; Intapan, P. M.; Maleewong, W.; Brindley, P. J. Food-borne trematodiases in Southeast Asia: Epidemiology, pathology, clinical manifestation and control. Advances in Parasitology, v. 72, p. 305-350, 2010. https://doi.org/10.1016/S0065308X(10)72011-X

Tandon, V.; Shylla, J. A.; Ghatani, S.; Athokpam, V. D.; Sahu, R. Neglected Tropical Diseases: Trematodiases - The Indian Scenario. Proceedings of the National Academy of Sciences, India Section B: Biological Sciences, v. 85, no. 4, p. 901-907, 2014. https://doi.org/10.1007/s40011-0140465-x
Toledo, R.; Esteban, J. G. An update on human echinostomiasis. Transactions of the Royal Society of Tropical Medicine \& Hygiene, v. 110 , p. $37-45,2016$ https://doi.org/ 10.1093/trstmh/trv099

Toledo, R.; Esteban, J. G.; Fried, B. Recent advances in the biology of echinostomes. Advances in Parasitology, v. 69, p. 147-204, $2009 . \quad$ https://doi.org/10.1016/S0065308X(09)69003-5

Yamaguti, S. Systema helminthum. In: Yamaguti, S. (Ed.). The digenetic trematodes of vertebrates. New York: Interscience, 1958. v. 1. 